\title{
Syntheses and Characterization of the Coordination Compounds of $\mathrm{N}$-(2-hydroxymethylphenyl)-C- (3'-carboxy-2' -hydroxyphenyl)thiazolidin-4-one
}

\author{
Dinesh Kumar, ${ }^{1}$ Amit Kumar, ${ }^{2}$ and Durga Dass ${ }^{3}$ \\ ${ }^{1}$ Department of Chemistry, National Institute of Technology, Haryana, Kurukshetra 136119, India \\ ${ }^{2}$ Department of Chemistry, Haryana College of Technology \& Management, Haryana, Kaithal 136027, India \\ ${ }^{3}$ Department of Chemistry, Shri Krishan Institute of Engineering \& Technology, Haryana, Kurukshetra 136118, India
}

Correspondence should be addressed to Amit Kumar; amit_vashistha2004@yahoo.co.in

Received 26 December 2012; Accepted 7 February 2013

Academic Editor: Hakan Arslan

Copyright (C) 2013 Dinesh Kumar et al. This is an open access article distributed under the Creative Commons Attribution License, which permits unrestricted use, distribution, and reproduction in any medium, provided the original work is properly cited.

A dry benzene solution of the Schiff base N-(2-hydroxymethylphenyl)-3' -carboxy-2' -hydroxybenzylideneimine upon reacting with mercaptoacetic acid undergoes cyclization and forms N-(2-hydroxymethylphenyl)-C-(3' -carboxy-2' -hydroxyphenyl)thiazolidin4-one, $\mathrm{LH}_{3}$ (I). A MeOH solution of I reacts with $\mathrm{Co}(\mathrm{II}), \mathrm{Ni}(\mathrm{II}), \mathrm{Cd}(\mathrm{II}), \mathrm{Zr}(\mathrm{OH})_{2}$ (IV), and $\mathrm{UO}_{2}$ (VI) ions and forms the monomeric coordination compounds, $\left[\mathrm{M}(\mathrm{LH})(\mathrm{MeOH})_{3}\right]$ [where $\left.\mathrm{M}=\mathrm{Co}(\mathrm{II}), \mathrm{Ni}(\mathrm{II})\right],\left[\mathrm{M}^{\prime}(\mathrm{LH})(\mathrm{MeOH})\right]\left[\right.$ here $\left.\mathrm{M}^{\prime}=\mathrm{Cd}(\mathrm{II}), \mathrm{UO} \mathrm{O}_{2}(\mathrm{VI})\right]$ and $\left[\mathrm{Zr}(\mathrm{OH})_{2}(\mathrm{LH})(\mathrm{MeOH})\right]$. The coordination compounds have been characterized on the bases of elemental analyses, molar conductance, molecular weight, spectral (IR, NMR, and reflectance) studies, and magnetic susceptibility measurements. I behaves as a dibasic tridentate OOS donor ligand in these compounds. The compounds are nonelectrolytes $\left(\Lambda_{\mathrm{M}}=3.8-8.9 \mathrm{mho} \mathrm{cm}^{2} \mathrm{~mol}^{-1}\right)$ in DMF. A tetrahedral structure for $[\mathrm{Cd}(\mathrm{LH})(\mathrm{MeOH})]$ and an octahedral structure for the remaining compounds are suggested.

\section{Introduction}

The chemistry of thiazolidin-4-ones is very well documented in the literature and has been studied extensively due to their versatile biological properties [1]. Thiazolidin-4-ones, a saturated form of thiazole with carbonyl group on fourth carbon [2], have biological activities like those that are antipsychotic [3], antitubercular [4], antibacterial [5], anticonvulsant [6], antifungal [7], amoebicidal [8], antioxidant [9], antibiotic $[10]$, and so forth.

Literature survey shows that much has been reported on the syntheses and characterization [11] of a variety of thiazolidin-4-ones, but very less is known about their coordination compounds [12-14].

Metal complexes play an important role in plant and animal life due to their physicochemical and biological properties. Metal ions are involved in specific interactions with antibiotics, proteins, nucleic acids, and other biomolecules [15]. Most of the drugs have improved pharmacological properties in the form of their metal complexes. Transition metal ions play a very important role in the pharmacological action of metal-based drugs and these drugs are more effective against infectious microbes than the uncomplexed drugs [16].

These facts motivate us to explore the coordination behavior of a newly synthesized thiazolidin-4-one with some transition metal ions.

In this paper, we describe the syntheses and characterization of N-(2-hydroxymethylphenyl)-C-(3'-carboxy-2 hydroxyphenyl)thiazolidin-4-one, $\mathrm{LH}_{3}(\mathrm{I})$ and its coordination compounds with $\mathrm{Co}(\mathrm{II}), \mathrm{Ni}(\mathrm{II}), \mathrm{Cd}(\mathrm{II}), \mathrm{Zr}(\mathrm{OH})_{2}(\mathrm{IV})$, and $\mathrm{UO}_{2}(\mathrm{VI})$ ions. The structure of Schiff base and thiazolidin-4-one, $\mathrm{LH}_{3}(\mathrm{I})$ is shown in Figure 1. 
<smiles>O=C(O)c1cccc(/C=N/c2ccccc2C(O)O)c1O</smiles>

[Schiff base]

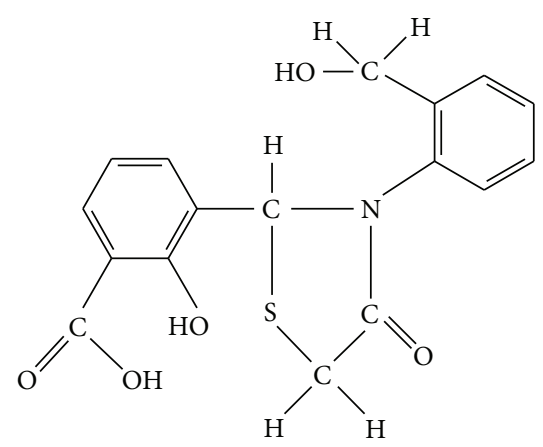

[I]

Figure 1

\section{Experimental}

2.1. Materials. o-Aminobenzylalcohol [Aldrich]; nickel(II) acetate tetrahydrate, cadmium(II) acetate dihydrate, dioxouranium(VI) acetate tetrahydrate (Sarabhai); cobalt(II) acetate tetrahydrate, hexadecaaquaoctahydroxotetrazirconium(IV) chloride (BDH); methanol, ethanol, mercaptoacetic acid, dry benzene, and sodium bicarbonate (Ranbaxy) were used as supplied for the syntheses. 3-Formylsalicylic acid [17] and hexadecaaquaoctahydroxotetrazirconium(IV) acetate [18] were synthesized by the following reported procedures.

2.2. Analyses and Physical Measurements. The organic skeleton of the respective coordination compounds was decomposed by the slow heating of $\sim 0.1 \mathrm{~g}$ of the latter, with conc. $\mathrm{HNO}_{3}$. The residue was dissolved in a minimum amount of conc. $\mathrm{HCl}$ and the corresponding metal ions were estimated as follows: the $\mathrm{Ni}$ (II) contents of the respective coordination compound were estimated by complexometric titration method against standardized EDTA solution using murexide as an indicator. The $\mathrm{Co}(\mathrm{II})$ and $\mathrm{Cd}(\mathrm{II})$ contents in the respective coordination compounds were estimated by the complexometric titration method against standardized EDTA solution using xylenol orange as an indicator. The uranium content in $\left[\mathrm{UO}_{2}(\mathrm{LH})(\mathrm{MeOH})\right]$ was estimated gravimetrically as $\mathrm{U}_{3} \mathrm{O}_{8}$ after decomposing the compound with a few drops of conc. $\mathrm{HNO}_{3}$ and then igniting the residue. The zirconium contents were estimated gravimetrically as $\mathrm{ZrO}_{2}$ after decomposing the corresponding compound with a few drops of conc. $\mathrm{HNO}_{3}$ and then igniting the residue. The $\mathrm{C}, \mathrm{H}$, and $\mathrm{N}$ contents of $\mathrm{LH}_{3}$ and its coordination compounds were determined by CHN Eager analyzer model300. The $\mathrm{S}$ and $\mathrm{Cl}$ contents were estimated gravimetrically as $\mathrm{BaSO}_{4}$ and $\mathrm{AgCl}$, respectively. The molecular weight measurements were carried out by the Rast method using diphenyl as the solvent [19]. The molar conductances $\left(\Lambda_{M}\right)$ of the coordination compounds were measured in DMF with the help of a Toshniwal conductivity bridge (CL01-02A) and a dip-type cell calibrated with $\mathrm{KCl}$ solutions. The IR spectra were recorded in $\mathrm{KBr}$ pellets $\left(4000-400 \mathrm{~cm}^{-1}\right.$ ) on a Beckman 20 spectrophotometer. The reflectance spectra were recorded on a Beckmann DU spectrophotometer attached with a reflectance arrangement. The magnetic susceptibility measurements were carried out at room temperature, using $\mathrm{Hg}\left[\mathrm{Co}(\mathrm{NCS})_{4}\right]$ as the standard [20]. The diamagnetic corrections were computed using Pascal's constants. The magnetic susceptibilities were corrected for temperature-independent paramagnetism term (TIP) [20] using a value of $200 \times 10^{-6} \mathrm{cgs}$ units for $\mathrm{Ni}(\mathrm{II})$ and $\mathrm{Co}(\mathrm{II})$ ions.

2.3. Synthesis of the $N$-(2-hydroxymethylphenyl)-3'-carboxy2 -hydroxybenzylide-neimine (Schiff Base). A $\mathrm{MeOH}$ solution $(30 \mathrm{~mL})$ of $o$-aminobenzylalcohol $(1.23 \mathrm{~g}, 10 \mathrm{mmol})$ was added to a $\mathrm{MeOH}$ solution $(30 \mathrm{~mL})$ of 3 -formylsalicylic acid $(1.66 \mathrm{~g}, 10 \mathrm{mmol})$ and the mixture was then refluxed for $1 \mathrm{~h}$. The precipitates formed were suction filtered, washed with $\mathrm{MeOH}$, and dried in vacuo at room temperature over silica gel for $24 \mathrm{~h}$. Yield $=58 \%$. The elemental analyses of the compound gave the satisfactory results.

2.4. Synthesis of N-(2-hydroxymethylphenyl)-C-(3'-carboxy2'-hydroxyphenyl)thiazolidin-4-one (I). A dry benzene solution of the Schiff base $(2.71 \mathrm{~g}, 10 \mathrm{mmol})$ and mercaptoacetic acid $(0.92 \mathrm{~g}, 10 \mathrm{mmol})$ were refluxed for $12 \mathrm{~h}$ in a water bath. The mixture was cooled to room temperature and then was washed with $10 \%$ sodium bicarbonate solution. The benzene layer was separated using a separating funnel. The partial evaporation of the benzene layer gave a solid product, which was filtered, washed with petroleum ether and recrystallized from petroleum ether. The compounds were dried as mentioned above. Yield $=14 \%$. Anal: $\left(\mathrm{I}, \mathrm{C}_{17} \mathrm{H}_{15} \mathrm{NO}_{5} \mathrm{~S}\right)$ (obsd: C, 58.91\%; H, 4.37\%; N, 4.12\%; S, 9.11\%. calc.: C, 59.13\%; H, 4.35\%; N, 4.06\%; S, 9.28\%); IR bands (KBr): $2860 \mathrm{~cm}^{-1}[v(\mathrm{O}-\mathrm{H})$ (intramolecular H-bonding) $], 1710 \mathrm{~cm}^{-1}$ $[v(\mathrm{C}=\mathrm{O})$ (thiazolidinone ring) $], 1675 \mathrm{~cm}^{-1}[v(\mathrm{C}=\mathrm{O})($ carboxylic) $], 1570 \mathrm{~cm}^{-1}\left[v(\mathrm{C}-\mathrm{N})(\right.$ thiazolidinone ring) $], 1520 \mathrm{~cm}^{-1}$ $[v(\mathrm{C}-\mathrm{O})($ phenolic $)], 1225 \mathrm{~cm}^{-1}[v(\mathrm{C}-\mathrm{O})($ alcoholic $)]$, and $830 \mathrm{~cm}^{-1}[v(\mathrm{C}-\mathrm{S})($ thiazolidinone ring) $]$.

2.5. Syntheses of Coordination Compounds of I. A $\mathrm{MeOH}$ solution $(30-50 \mathrm{~mL})$ of the appropriate metal salt $(10 \mathrm{mmol})$ was added to a $\mathrm{MeOH}$ solution $(50 \mathrm{~mL})$ of $\mathbf{I}(3.45 \mathrm{~g}, 10 \mathrm{mmol})$ and the mixture was then refluxed for 3-4h. The solid products formed were suction filtered, washed with $\mathrm{MeOH}$ 
TABLE 1: Analytical, molar conductance $\left(\Lambda_{\mathrm{M}}\right)$, and molecular weight data of I and its coordination compounds.

\begin{tabular}{|c|c|c|c|c|c|c|c|c|}
\hline \multirow{2}{*}{ Compound } & \multirow{2}{*}{ Mol. formula } & \multirow{2}{*}{$\Lambda_{\mathrm{M}}\left(\mathrm{mho} \mathrm{cm}{ }^{2} \mathrm{Mol}^{-1}\right)$} & \multirow{2}{*}{ Mol. wt obsd (calcd) } & \multicolumn{5}{|c|}{ Obsd (calcd)\% } \\
\hline & & & & M & $\mathrm{C}$ & $\mathrm{H}$ & $\mathrm{N}$ & S \\
\hline $\mathrm{LH}_{3}(\mathbf{I})$ & $\mathrm{C}_{17} \mathrm{H}_{15} \mathrm{NO}_{5} \mathrm{~S}$ & - & $345^{\mathrm{a}}(345.0)$ & - & $\begin{array}{c}58.91 \\
(59.13)\end{array}$ & $\begin{array}{c}4.37 \\
(4.35)\end{array}$ & $\begin{array}{c}4.12 \\
(4.06)\end{array}$ & $\begin{array}{c}9.11 \\
(9.28)\end{array}$ \\
\hline$\left[\mathrm{Co}(\mathrm{LH})(\mathrm{MeOH})_{3}\right]$ & $\mathrm{CoC}_{20} \mathrm{H}_{25} \mathrm{NO}_{8} \mathrm{~S}$ & 4.8 & $511.6^{\mathrm{b}}(497.9)$ & $\begin{array}{c}11.64 \\
(11.83)\end{array}$ & $\begin{array}{c}48.37 \\
(48.20)\end{array}$ & $\begin{array}{c}5.10 \\
(5.02)\end{array}$ & $\begin{array}{c}2.74 \\
(2.81)\end{array}$ & $\begin{array}{c}6.32 \\
(6.43)\end{array}$ \\
\hline$\left[\mathrm{Ni}(\mathrm{LH})(\mathrm{MeOH})_{3}\right]$ & $\mathrm{NiC}_{20} \mathrm{H}_{25} \mathrm{NO}_{8} \mathrm{~S}$ & 3.8 & $481.3^{\mathrm{b}}(497.7)$ & $\begin{array}{c}11.56 \\
(11.79)\end{array}$ & $\begin{array}{c}48.17 \\
(48.22)\end{array}$ & $\begin{array}{c}5.17 \\
(5.02)\end{array}$ & $\begin{array}{c}2.72 \\
(2.81)\end{array}$ & $\begin{array}{c}6.28 \\
(6.43)\end{array}$ \\
\hline$[\mathrm{Cd}(\mathrm{LH})(\mathrm{MeOH})]$ & $\mathrm{CdC}_{18} \mathrm{H}_{17} \mathrm{NO}_{6} \mathrm{~S}$ & 7.7 & $511.2^{\mathrm{b}}(487.4)$ & $\begin{array}{c}23.17 \\
(23.06)\end{array}$ & $\begin{array}{c}44.50 \\
(44.32)\end{array}$ & $\begin{array}{c}3.53 \\
(3.49)\end{array}$ & $\begin{array}{c}2.72 \\
(2.87)\end{array}$ & $\begin{array}{c}6.49 \\
(6.56)\end{array}$ \\
\hline$\left[\mathrm{Zr}(\mathrm{OH})_{2}(\mathrm{LH})(\mathrm{MeOH})\right]$ & $\mathrm{ZrC}_{18} \mathrm{H}_{19} \mathrm{NO}_{8} \mathrm{~S}$ & 8.9 & $517.2^{\mathrm{b}}(500.2)$ & $\begin{array}{c}18.06 \\
(18.23)\end{array}$ & $\begin{array}{c}43.34 \\
(43.18)\end{array}$ & $\begin{array}{c}3.74 \\
(3.80)\end{array}$ & $\begin{array}{c}2.85 \\
(2.80)\end{array}$ & $\begin{array}{c}6.32 \\
(6.40)\end{array}$ \\
\hline$\left[\mathrm{UO}_{2}(\mathrm{LH})(\mathrm{MeOH})\right]$ & $\mathrm{UC}_{18} \mathrm{H}_{17} \mathrm{NO}_{8} \mathrm{~S}$ & 6.8 & $659.5^{\mathrm{b}}(645.0)$ & $\begin{array}{c}36.67 \\
(36.90)\end{array}$ & $\begin{array}{c}33.24 \\
(33.49)\end{array}$ & $\begin{array}{c}2.45 \\
(2.64)\end{array}$ & $\begin{array}{c}2.05 \\
(2.17)\end{array}$ & $\begin{array}{c}4.85 \\
(4.96)\end{array}$ \\
\hline
\end{tabular}

Mass spectral data. ${ }^{\mathrm{b}}$ Rast method data.

TABLE 2: IR, reflectance spectral data $\left(\mathrm{cm}^{-1}\right)$, and magnetic moments of the coordination compounds of $\mathbf{I}$.

\begin{tabular}{lccccccc}
\hline Compound & $v_{\text {as }}(\mathrm{COO})$ & $v_{\mathrm{s}}(\mathrm{COO})$ & $v(\mathrm{C}-\mathrm{O})($ phenolic $)$ & $v(\mathrm{C}-\mathrm{S})$ & $v(\mathrm{C}-\mathrm{O})(\mathrm{MeOH})$ & $v_{\max }$ & Mag. moment $(\mathrm{B} . \mathrm{M})$. \\
\hline $\mathrm{LH}_{3}(\mathrm{I})$ & - & - & 1520 & 830 & - & - & Diamagnetic \\
{$\left[\mathrm{Co}(\mathrm{LH})(\mathrm{MeOH})_{3}\right]$} & 1572 & 1358 & 1530 & 795 & 986 & $8700,13000,18550$ & 4.75 \\
{$\left[\mathrm{Ni}(\mathrm{LH})(\mathrm{MeOH})_{3}\right]$} & 1572 & 1352 & 1526 & 805 & 989 & $8980,15980,24900$ & 3.14 \\
{$[\mathrm{Cd}(\mathrm{LH})(\mathrm{MeOH})]$} & 1560 & 1347 & 1530 & 810 & 984 & - & Diamagnetic \\
{$\left[\mathrm{Zr}(\mathrm{OH})_{2}(\mathrm{LH})(\mathrm{MeOH})\right]$} & 1562 & 1337 & 1530 & 815 & 974 & - & Diamagnetic \\
{$\left[\mathrm{UO}_{2}(\mathrm{LH})(\mathrm{MeOH})\right]$} & 1567 & 1349 & 1529 & 810 & 980 & - & Diamagnetic \\
\hline
\end{tabular}

$$
\text { Schiff base } \underset{\text { Dry benzene }}{\stackrel{\mathrm{HS}}{\mathrm{C}} \mathrm{CH}_{2} \mathrm{COOH}} \mathbf{I}
$$

Scheme 1: Preparative scheme of $\mathrm{LH}_{3}$ (I).

and recrystallized from $\mathrm{MeOH}$ and were then dried as mentioned above. Yield $=50-75 \%$.

\section{Results and Discussion}

A dry benzene solution of the Schiff base reacts with mercaptoacetic acid and forms N-(2-hydroxymethylphenyl)C-(3'-carboxy-2' -hydroxyphenyl)thiazolidin-4-one, $\mathrm{LH}_{3}(\mathrm{I})$. The reaction of $\mathbf{I}$ with appropriate metal salt in $1: 1$ molar ratio in $\mathrm{MeOH}$ produces the coordination compounds, $\left[\mathrm{M}(\mathrm{LH})(\mathrm{MeOH})_{3}\right]$ [where $\left.\mathrm{M}=\mathrm{Co}(\mathrm{II}), \mathrm{Ni}(\mathrm{II})\right]$, $\left[\mathrm{M}^{\prime}(\mathrm{LH})(\mathrm{MeOH})\right]$ [where $\left.\mathrm{M}^{\prime}=\mathrm{Cd}(\mathrm{II}), \mathrm{UO}_{2}(\mathrm{VI})\right]$, and $\left[\mathrm{Zr}(\mathrm{OH})_{2}(\mathrm{LH})(\mathrm{MeOH})\right]$. The formations of $\mathbf{I}$ from the Schiff base and the coordination compounds of I take place according to Schemes 1 and 2 .

The coordination compounds are air-stable at room temperature. They are insoluble in $\mathrm{H}_{2} \mathrm{O}$, partially soluble in $\mathrm{MeOH}, \mathrm{EtOH}$, and completely soluble in DMSO and DMF. Their molar conductance measurements $\left(\Lambda_{M}\right.$ $=3.8-8.9 \mathrm{mho} \mathrm{cm}^{2} \mathrm{~mol}^{-1}$ ) in DMF indicate their nonelectrolytic nature. The analytical data of $\mathbf{I}$ and its coordination compounds are presented in Table 1.
3.1. Infrared Spectral Studies. The infrared spectra of I and its coordination compounds were recorded in $\mathrm{KBr}$ and the prominent peaks (in $\mathrm{cm}^{-1}$ ) are shown in Table 2 . The Schiff base exhibits the $v(\mathrm{C}=\mathrm{N})$ (azomethine) stretch at $1640 \mathrm{~cm}^{-1}$. This band disappears in $\mathbf{I}$ and a new band appears at $1570 \mathrm{~cm}^{-1}$ due to the $v(\mathrm{C}-\mathrm{N})$ (thiazolidinone ring) stretch [21] indicating the conversion of the Schiff base into $\mathbf{I}$. The formation of $\mathbf{I}$ is further supported by the appearance of a new band at $830 \mathrm{~cm}^{-1}$ due to the $v(\mathrm{C}-\mathrm{S})($ thiazolidinone ring) stretch [22]. A negative shift of $15-35 \mathrm{~cm}^{-1}$ of the $v(\mathrm{C}-\mathrm{S})$ (thiazolidinone ring) stretch in the coordination compounds indicates the involvement of the $S$ atom of the thiazolidinone moiety in coordination [14]. I shows the $v(\mathrm{C}=\mathrm{O})$ (thiazolidinone ring) stretch [23] at 1710 $\mathrm{cm}^{-1}$. This band remains unchanged in the coordination compounds indicating the noninvolvement of $\mathrm{O}$ atom in the coordination. The $v(\mathrm{C}-\mathrm{O})$ (alcoholic) stretch [24] of I occurs at $1225 \mathrm{~cm}^{-1}$ which remains unchanged in the complexes. I exhibits a strong band at $2860 \mathrm{~cm}^{-1}$ due to the intramolecular $\mathrm{H}$-bonded $\mathrm{OH}$ group of phenolic and/or carboxylic acid moieties [25]. This band disappears in the coordination compounds indicating the breakdown of $\mathrm{H}$ bonding and subsequent deprotonation of the $\mathrm{OH}$ group followed by the involvement of phenolic and carboxylic acid $\mathrm{O}$ atoms in coordination. The presence of a broadband at $\sim 3400 \mathrm{~cm}^{-1}$ due to $v(\mathrm{O}-\mathrm{H})(\mathrm{MeOH})$ and the decrease of $v(\mathrm{C}-\mathrm{O})(\mathrm{MeOH})$ stretch from $1034 \mathrm{~cm}^{-1}$ to lower energy by $45-60 \mathrm{~cm}^{-1}$ in the coordination compounds of $I$ indicate the 


$$
\begin{aligned}
& \mathrm{LH}_{3}+\mathrm{M}(\mathrm{OAc})_{2} \cdot 4 \mathrm{H}_{2} \mathrm{O} \underset{\text { Reflux }}{\stackrel{\mathrm{MeOH}}{\longrightarrow}}\left[\mathrm{M}(\mathrm{LH})(\mathrm{MeOH})_{3}\right]+2 \mathrm{AcOH}+4 \mathrm{H}_{2} \mathrm{O} \\
& \text { [M = Co(II), Ni(II)] }
\end{aligned}
$$

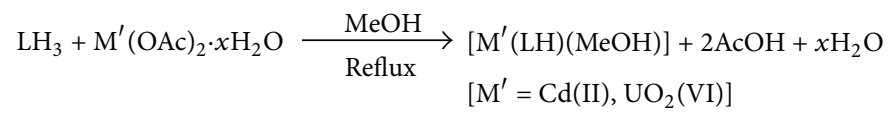

$$
\begin{aligned}
& 4 \mathrm{LH}_{3}+\left[\mathrm{Zr}_{4}(\mathrm{OH})_{8}\left(\mathrm{H}_{2} \mathrm{O}\right)_{16}\right](\mathrm{OAc})_{8} \underset{\text { Reflux }}{\stackrel{\mathrm{MeOH}}{\longrightarrow}} 4\left[\mathrm{Zr}(\mathrm{OH})_{2}(\mathrm{LH})(\mathrm{MeOH})\right]+8 \mathrm{AcOH}+16 \mathrm{H}_{2} \mathrm{O}
\end{aligned}
$$

Scheme 2: Preparative scheme of coordination compounds of $\mathrm{LH}_{3}$ (I).

involvement of the $\mathrm{O}$ atom of $\mathrm{MeOH}$ in coordination [26]. The appearance of two new bands between $1560-1572 \mathrm{~cm}^{-1}$, $v_{\text {as }}(\mathrm{COO})$ and $1337-1358 \mathrm{~cm}^{-1}, v_{\mathrm{s}}(\mathrm{COO})$ stretches indicates the presence of the coordinated carboxylate group in the coordination compounds. The energy difference $(\Delta v=$ $213-225 \mathrm{~cm}^{-1}$ ) between these stretches is $>210 \mathrm{~cm}^{-1}$ which indicates the monodentate nature of the carboxylate moiety [27]. The $v(\mathrm{C}-\mathrm{O}) \phi$ stretch of I occurs at $1520 \mathrm{~cm}^{-1}$. This band shifts to higher energy by $6-10 \mathrm{~cm}^{-1}$ in the coordination compounds indicating the involvement of phenolic $\mathrm{O}$ atom of 3 -formylsalicylic acid moiety in coordination [26]. The absence of a band between $835-955 \mathrm{~cm}^{-1}$ due to the $v(\mathrm{Zr}=\mathrm{O})$ stretch [28] in the present $\mathrm{Zr}(\mathrm{OH})_{2}(\mathrm{IV})$ compound suggests its formulation as $\left[\mathrm{Zr}(\mathrm{OH})_{2}(\mathrm{LH})(\mathrm{MeOH})\right]$ and not as $\left[\mathrm{ZrO}\left(\mathrm{H}_{2} \mathrm{O}\right)(\mathrm{LH})(\mathrm{MeOH})\right]$ [29]. The presence of a broadband at $3440 \mathrm{~cm}^{-1}$ due to $v(\mathrm{OH})$ stretch and the appearance of a new medium intense band at $1135 \mathrm{~cm}^{-1}$ due to the $\delta(\mathrm{Zr}-\mathrm{OH})$ bending mode [29] also support the proposed structure of the present $\mathrm{Zr}(\mathrm{OH})_{2}(\mathrm{IV})$ compound. $\left[\mathrm{UO}_{2}(\mathrm{LH})(\mathrm{MeOH})\right]$ exhibits the $v_{\mathrm{as}}(\mathrm{O}=\mathrm{U}=\mathrm{O})$ stretch at $898 \mathrm{~cm}^{-1}$ and this band occurs in the usual range (870-950 $\mathrm{cm}^{-1}$ ) observed for the majority of trans- $\mathrm{UO}_{2}(\mathrm{VI})$ compounds [30]. The force constant $\left(f_{\mathrm{U}_{-} \mathrm{O}}\right)$ and $\mathrm{U}-\mathrm{O}$ bond length in the present dioxouranium(VI) compound are $6.70 \mathrm{mdyn} / \AA$ and $1.74 \AA$, respectively. These values are in the expected range (6.58-7.03 mdyn/ $\AA$ and $1.60-1.92 \AA$ ) reported for the majority of $\mathrm{UO}_{2}(\mathrm{VI})$ compounds [29]. The new nonligand bands in the present coordination compounds in the low-frequency region are assigned to the $v(\mathrm{M}-\mathrm{O})\left(550-570 \mathrm{~cm}^{-1}\right)$ and the $v(\mathrm{M}-\mathrm{S})\left(345-375 \mathrm{~cm}^{-1}\right)$ and these bands [31] are in the expected order of increasing energy: $v(\mathrm{M}-\mathrm{S})<v(\mathrm{M}-\mathrm{O})$.

3.2. NMR Spectral Studies. The NMR spectra of I and its coordination compounds were recorded in DMSO- $d_{6}$. The chemical shifts $(\delta)$ are expressed in ppm downfield from TMS. The prominent resonance signals of these compounds were compared with the reported peaks [32]. I exhibits a singlet at $\delta 17.5 \mathrm{ppm}$ due to the carboxylic proton, a sharp singlet at $\delta 13.60 \mathrm{ppm}$ due to phenolic proton, a singlet at $\delta 2.35 \mathrm{ppm}$ due to alcoholic proton, multiplets due to methylene protons at $\delta$ 4.70-4.79 ppm, and multiplets between $\delta 7.34$ and $7.50 \mathrm{ppm}$ due to the aromatic protons. The occurrence of the resonance signal at the same frequency $(\delta 2.35 \mathrm{ppm})$ due to alcoholic proton $\left(\mathrm{CH}_{2} \mathrm{OH}\right)$ indicates the noninvolvement of the alcoholic group in coordination. The absence of the signal at $\delta 17.5 \mathrm{ppm}$ due to the $\mathrm{COOH}$ proton in the coordination compounds indicates the deprotonation of the $\mathrm{COOH}$ group, followed by the involvement of its $\mathrm{O}$ atom in coordination. The absence of the resonance signal at $\delta 13.60 \mathrm{ppm}$ due to the phenolic proton in the coordination compounds indicates the deprotonation of the phenolic $\mathrm{OH}$ group followed by its involvement in coordination [26]. The appearance of resonance signals at 2.81-2.85 ppm due to alcoholic proton and at 3.0-3.1 ppm due to methyl protons in the coordination compounds supports the presence of $\mathrm{MeOH}$ in these compounds.

3.3. Reflectance Spectral Studies. The presence of three bands at 8700,13000, and $18550 \mathrm{~cm}^{-1}$ due to ${ }^{4} T_{1 g}(F) \rightarrow$ ${ }^{4} T_{2 g}\left(\nu_{1}\right),{ }^{4} T_{1 g}(F) \rightarrow{ }^{4} A_{2 g}\left(\nu_{2}\right)$, and ${ }^{4} T_{1 g}(F) \rightarrow{ }^{4} T_{1 g}\left(\nu_{3}\right)$ transitions, respectively, suggests an octahedral arrangement of $\mathbf{I}$ around $\mathrm{Co}(\mathrm{II})$ ions in $\left[\mathrm{Co}(\mathrm{LH})(\mathrm{MeOH})_{3}\right]$ [33]. The value of $v_{3} / \nu_{1}$ (2.13) lies in the range 2.00-2.80, reported for most of the octahedral $\mathrm{Co}$ (II) compounds [33]. The spectral parameters [33-35] for $\left[\mathrm{Co}(\mathrm{LH})(\mathrm{MeOH})_{3}\right]$ are $\mathrm{Dq}=$ $979 \mathrm{~cm}^{-1}, B^{\prime}=729 \mathrm{~cm}^{-1}, \beta=B^{\prime} / B=0.75, \beta^{0}=25 \%$, and CFSE $=-93.57 \mathrm{~kJ} \mathrm{~mol}^{-1}$. Reduction of Racah parameter from $971 \mathrm{~cm}^{-1}$ (free ion value) to $729 \mathrm{~cm}^{-1}$ and the $\beta^{0}$ value $(25 \%)$ indicate the covalent nature of the compound and strong field nature of $\mathbf{I}[20]$. $\left[\mathrm{Ni}(\mathrm{LH})(\mathrm{MeOH})_{3}\right]$ shows three bands at 8980, 15980, and $24900 \mathrm{~cm}^{-1}$ due to ${ }^{3} A_{2 g}(F) \rightarrow$ ${ }^{3} T_{2 g}(F)\left(v_{1}\right),{ }^{3} A_{2 g}(F) \rightarrow{ }^{3} T_{1 g}(F)\left(v_{2}\right)$, and ${ }^{3} A_{2 g}(F) \rightarrow$ ${ }^{3} T_{1 g}(P)\left(v_{3}\right)$ transitions, respectively, in an octahedral symmetry [33]. The value of $v_{2} / v_{1}$ is 1.78 which lies in the usual range (1.60-1.82), reported for the majority of octahedral $\mathrm{Ni}(\mathrm{II})$ compounds. The spectral parameters [34, 35] for $\left[\mathrm{Ni}(\mathrm{LH})(\mathrm{MeOH})_{3}\right]$ are $D q=898 \mathrm{~cm}^{-1}, B^{\prime}=843 \mathrm{~cm}^{-1}$, $\beta=B^{\prime} / B=0.82, \beta^{0}=18 \%$, and CFSE $=-128.75 \mathrm{~kJ} \mathrm{~mole}^{-1}$. The reduction of the Racah parameter from the free ion value $\left(1030 \mathrm{~cm}^{-1}\right)$ to $843 \mathrm{~cm}^{-1}$ and the $\beta^{0}$ value $(18 \%)$ are indicative of the presence of covalent nature of the compound and the strong field nature of the tridentate ligand (I) [20]. For a given ligand and given stereochemistry, the covalent character of the corresponding $\mathrm{Co}$ (II) and $\mathrm{Ni}(\mathrm{II})$ coordination compounds is comparable since $\mathrm{Co}(\mathrm{II})$ and $\mathrm{Ni}$ (II) 


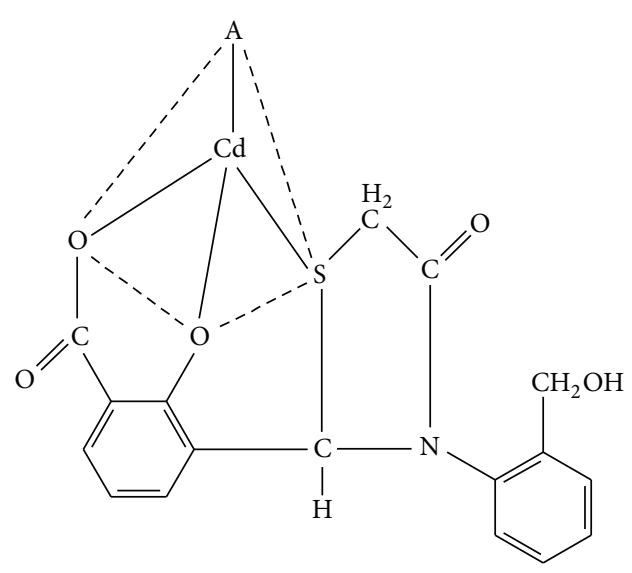

[II, $\mathrm{A}=\mathrm{MeOH}]$

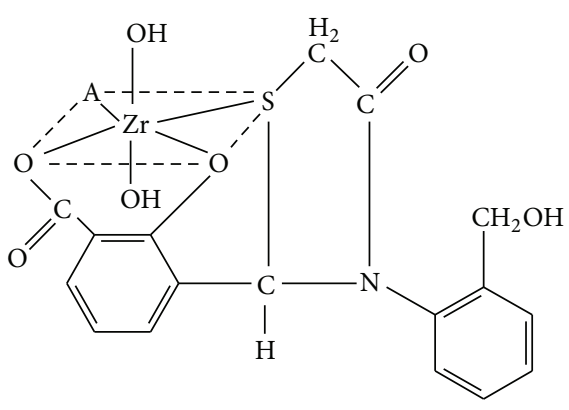

$[\mathbf{I V}, \mathrm{A}=\mathrm{MeOH}]$

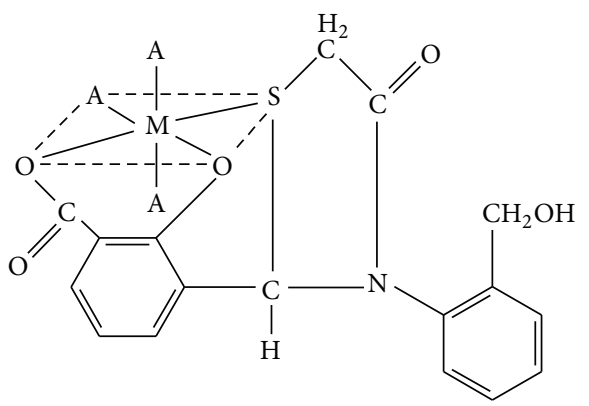

[III, $\mathrm{M}=\mathrm{Co}(\mathrm{II}), \mathrm{Ni}(\mathrm{II}) ; \mathrm{A}=\mathrm{MeOH}]$

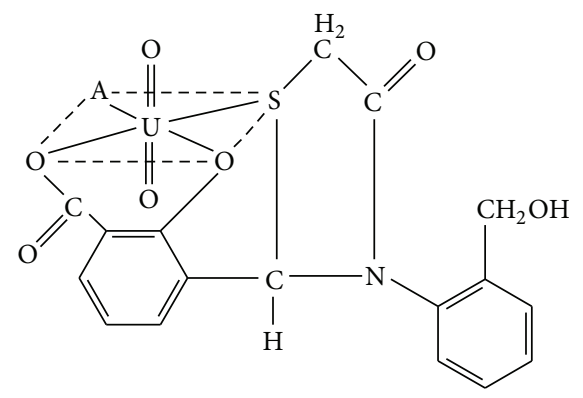

$[\mathbf{V}, \mathrm{A}=\mathrm{MeOH}]$

Figure 2

occupy the adjacent positions in the nephelauxetic metal ion series (i.e., $\mathrm{Co}(\mathrm{II}) \sim \mathrm{Ni}(\mathrm{II})$ ) [20]. In the present $\mathrm{Co}(\mathrm{II})$ and $\mathrm{Ni}$ (II) coordination compounds, the $\beta^{0}$ values are quite comparable: $\left[\mathrm{Co}(\mathrm{LH})(\mathrm{MeOH})_{3}\right]: 25 \% ;\left[\mathrm{Ni}(\mathrm{LH})(\mathrm{MeOH})_{3}\right]$ : $18 \%$. For a given ligand and given stereochemistry, the spectrochemical series of metal ions on the basis of increasing $10 \mathrm{Dq}$ values is $\mathrm{Ni}(\mathrm{II})<\mathrm{Co}(\mathrm{II})$. Our calculated $10 \mathrm{Dq}$ values indicate that the $10 \mathrm{Dq}$ values are in the expected order: $\mathrm{Ni}(\mathrm{II})<\mathrm{Co}(\mathrm{II})$. The greater negative $\mathrm{CFSE}$ value $\left(-128.75 \mathrm{~kJ} \mathrm{~mol}^{-1}\right)$ for $\left[\mathrm{Ni}(\mathrm{LH})(\mathrm{MeOH})_{3}\right]$ in comparison to that of $\left[\mathrm{Co}(\mathrm{LH})(\mathrm{MeOH})_{3}\right]\left(\mathrm{CFSE}=-93.57 \mathrm{~kJ} \mathrm{~mol}^{-1}\right)$ is as expected [35].

3.4. Magnetic Measurements. The room temperature magnetic moments of the coordination compounds of I are presented in Table 2. The magnetic moments of $\left[\mathrm{Co}(\mathrm{LH})(\mathrm{MeOH})_{3}\right]$ and $\left[\mathrm{Ni}(\mathrm{LH})(\mathrm{MeOH})_{3}\right]$ are 4.75 and 3.14 B.M., respectively. These values are indicative of the magnetically dilute high-spin octahedral coordination compounds of $\mathrm{Co}(\mathrm{II})$ and $\mathrm{Ni}(\mathrm{II})$ ions [36]. The coordination compounds of other ions are diamagnetic.

Thus, on the basis of analytical data, valence requirements, molecular weight, spectral and the magnetic studies, it is proposed that $\mathbf{I}$ behaves as a dibasic tridentate OOS donor ligand in the tetrahedral compound, $[\mathrm{Cd}(\mathrm{LH})(\mathrm{MeOH})](\mathrm{II})$ and in the octahedral compounds, $\left[\mathrm{M}(\mathrm{LH})(\mathrm{MeOH})_{3}\right][$ where
$\mathrm{M}=\mathrm{Co}(\mathrm{II}), \mathrm{Ni}(\mathrm{II})](\mathrm{III}),\left[\mathrm{Zr}(\mathrm{OH})_{2}(\mathrm{LH})(\mathrm{MeOH})\right](\mathbf{I V})$ and for $\left[\mathrm{UO}_{2}(\mathrm{LH})(\mathrm{MeOH})\right](\mathrm{V})$, as shown in Figure 2.

\section{References}

[1] M. Abhinit, M. Ghodke, and N. A. Pratima, "Exploring potential of 4-thiazolidinone: a brief review," International Journal of Pharmacy and Pharmaceutical Sciences, no. 1, pp. 47-64, 2009.

[2] D. A. Horton, G. T. Bourne, and M. L. Smyth, "The combinatorial synthesis of bicyclic privileged structures or privileged substructures," Chemical Reviews, vol. 103, no. 3, pp. 893-930, 2003.

[3] N. J. Hrib, J. G. Jurcak, and J. G. Bregna, "3[4-[1-(6-Fluorobenzo[b]thiophen-3-yl)-4-piperazinyl]butyl]-2,5,5-trimethyl-4-thiazolidinone: a new atypical antipsychotic agent for the treatment of schizophrenia," Journal of Medicinal Chemistry, vol. 35, no. 14, pp. 2712-2715, 1992.

[4] A. Solanki and K. Kishore, "Synthesis and antitubercular activity of some 4-thiazolidinones," Asian Journal of Chemistry, vol. 6, no. 3, p. 177, 1994.

[5] B. P. Choudhari and V. V. Mulwad, "Synthesis of 1-(6-methylbenzofuran-2-yl)-3-aryl/[4-( $\beta$-substitutedethoxy)phenyl]propenones as marked anti-microbial agents," Indian Journal of Chemistry, vol. 44, p. 1074, 2005.

[6] N. J. Gaikwad and S. B. Agrawal, "Substituted 4-thiazolidinones as anticonvulsants VII," Indian Drugs, vol. 34, no. 9, pp. 542-543, 1997. 
[7] P. V. Patel and K. R. Desai, "Synthesis and anti-bacterial activity of new isoxazolines derivatives of 3,5-diaryl isoxazolines," Oriental Journal of Chemistry, vol. 18, no. 3, p. 311, 2002.

[8] N. C. Desai, B. R. Parekh, and K. A. Thaker, "Preparation of some important medicinal compounds. Thiosemicarbazones, thiadiazolines, 4-thiazolidinones and 5-arylidine derivatives as antibacterial and tuberculostatic agents," Journal of the Indian Chemical Society, vol. 64, no. 8, pp. 491-493, 1987.

[9] T. Kato, T. Ozaki, K. Tamura, Y. Suzuki, M. Akima, and N. Ohi, "Novel calcium antagonists with both calcium overload inhibition and antioxidant activity. 2. Structure-activity relationships of thiazolidinone derivatives," Journal of Medicinal Chemistry, vol. 42, no. 16, pp. 3134-3146, 1999.

[10] V. S. Ingle, A. R. Sawale, R. D. Ingle, and R. A. Mane, "Synthesis of new 4-thiazolidinones bearing potentially active heteryl moities," Indian Journal of Chemistry B, vol. 40, no. 2, pp. 124-128, 2001.

[11] S. B. Junne, S. S. Wadje, M. M. V. Baig, and Y. B. Vibhute, "Novel heterocyclic schiff bases, 4-thiazolidinones and 2-azetidinones possessing antibacterial and antifungal activity," International Journal of Chemical Sciences, vol. 5, p. 2093, 2007.

[12] D. Kumar and A. Kumar, "Syntheses, magnetic and spectral studies on the coordination compounds of the polystyrene anchored thiazolidin-4-one," E-Journal of Chemistry, vol. 9, no. 4, pp. 2532-2539, 2012.

[13] A. M. Rehab Al-Hasani, M. M. Sinan Al-byatti, and M. S. Sarab Al Azawi, "Synthesis, structural and biological studies of /3-(1, 3- benzothiazol-2-yl) - /4H- spiro[indole2,3-[1,3]thiazolidine]2,/4(1H) dion with $\mathrm{Cr}$ (III), Mn (II), Co (II), Ni (II), Cu (II), and Zn (II) ions," Engineering \& Technology Journal, vol. 29, no. 15, pp. 3067-3078, 2011.

[14] D. Kumar, A. Kumar, and J. Sharma, "Physico-chemical studies on the coordination compounds of thiazolidin-4-one," Journal of Chemistry, vol. 2013, Article ID 870325, 7 pages, 2013.

[15] J. R. Anacona and I. Rodriguez, "Synthesis and antibacterial activity of cephalexin metal complexes," Journal of Coordination Chemistry, vol. 57, no. 15, pp. 1263-1269, 2004.

[16] J. R. Anacona and J. Estacio, "Synthesis and antibacterial activity of cefixime metal complexes," Transition Metal Chemistry, vol. 31, no. 2, pp. 227-231, 2006.

[17] J. C. Duff and E. J. Bills, "The solubility of picric acid in mixed solvents. Part II. Benzene-alcohol mixtures," Journal Ofthe Chemical Society, pp. 881-884, 1932.

[18] A. Syamal and D. Kumar, "Syntheses of new zirconium (IV) complexes with the tridentate Schiff bases derived from oaminophenol and salicylaldehydes or 2-hydroxy-1-naphthaldehyde," Indian Journal of Chemistry A, vol. 24, p. 62, 1985.

[19] F. G. Mann and B. C. Saunders, Practical Organic Chemistry, Longmans, London, UK, 1961.

[20] R. L. Dutta and A. Syamal, Elements of Magnetochemistry, Affiliated East-West Press, New Delhi, India, 2nd edition, 1993.

[21] P. V. Patel and K. R. Desai, "Synthesis and anti-bacterial activity of new isoxazolines derivatives of 3,5-diaryl isoxazolines," Oriental Journal of Chemistry, vol. 18, no. 3, p. 311, 2002.

[22] D. C. Dash, A. Mahapatra, R. K. Mahapatra, S. Ghosh, and P. Naik, "Synthesis and characterization of dioxouranium(VI), thorium(IV), oxozirconium(IV) and oxovanadium(IV) complexes with 1,11-dihydroxy-1,4,5,7,8,11-hexaaza-2,3,9,10-tetramethyl-1,3,8,10-decatetraene-6- thione and their derivatives with chloroacetic acid," Indian Journal of Chemistry, vol. 47A, pp. 1009-1013, 2008.
[23] R. U. Roy and K. R. Desai, "Anticancer evaluation of azetidinone and thiazolidinone derivatives of quinolone," International Journal of Chemical Sciences, vol. 3, no. 3, p. 529, 2005.

[24] A. Syamal and O. P. Singhal, "New dioxouranium(VI)complexes with tridentate dibasic schiff bases containing ONO donor sets," Transition Metal Chemistry, vol. 4, no. 3, pp. 179-182, 1979.

[25] A. Syamal and D. Kumar, "New zirconium (IV) complexes with the ons donor triden tate schiff bases derived from salicyaldehyde or substituted salicylal dehydes and 2-aminobih anethiol," Synthesis and Reactivity in Inorganic and MetalOrganic Chemistry, vol. 14, no. 3, p. 325, 1984.

[26] D. Kumar, A. Syamal, A. Gupta, M. Rani, and P. K. Gupta, "Role of $\mathrm{pH}$ on the formation of the coordination compounds with the schiff base derived from 3-formylsalicylic acid and 4-amino2,3-dimethyl-1-phenyl-3-pyrazolin-5-one," Journal of the Indian Chemical Society, vol. 87, no. 10, pp. 1185-1197, 2010.

[27] J. R. Anacona and C. Toledo, "Synthesis and antibacterial activity of metal complexes of ciprofloxacin," Transition Metal Chemistry, vol. 26, no. 1-2, pp. 228-231, 2001.

[28] D. Kumar, A. Syamal, A. Kumar, P. K. Gupta, and D. Dass, "Syntheses and characterization of coordination compounds of $\mathrm{N}$-(2-mercaptoethyl)-4-(3'-carboxy-2' -hydroxyphenyl)-2azetidinone," Journal of the Indian Chemical Society, vol. 87, no. 4, pp. 417-423, 2010.

[29] D. Kumar, A. Syamal, and L. K. Sharma, "Synthesis and characterization of polystyrene-anchored monobasic bidentate schiff base and its complexes with bi-, tri-, tetra- and hexavalent metal ions," Journal of Coordination Chemistry, vol. 61, no. 11, pp. 1788-1796, 2008.

[30] D. Kumar, P. K. Gupta, A. Kumar, D. Dass, and A. Syamal, "Syntheses, spectroscopic, and magnetic properties of polystyreneanchored coordination compounds of tridentate ONO donor schiff base," Journal of Coordination Chemistry, vol. 64, no. 4, pp. 590-599, 2011.

[31] M. R. Charasia, "Cu(II), Ni(II) and $\mathrm{Co}(\mathrm{II})$ complexes of $\mathrm{N}$ phenyl-benzothiazolyl thiocarbamide," Journal of Inorganic and Nuclear Chemistry, vol. 37, no. 6, pp. 1547-1548, 1975.

[32] J. K. Nag, S. Pal, and C. Sinha, "Synthesis and characterization of cobalt(II), nickel(II), copper(II), palladium(II) and dioxouranium(VI) complexes of the antipyrine schiff base of 3formylsalicylic acid," Transition Metal Chemistry, vol. 30, no. 5, pp. 523-526, 2005.

[33] A. B. P. Lever, Inorganic Electronic Spectroscopy, Elsevier, Amsterdam, The Netherlands, 2nd edition, 1984.

[34] A. Syamal, D. Kumar, A. K. Singh et al., "Syntheses and characterization of a chelating resin containing ONO donor tridentate Schiff Base and its coordination compounds with copper (II). nickel(II), cobalt(II), iron(III), zinc(II), cadmium(II), manganese(II), molybdenum(VI), zirconium(IV) and uranium(VI)," Indian Journal of Chemistry, vol. 41, no. 7, pp. 1385-1390, 2002.

[35] J. E. Huheey, Inorganic Chemistry, Principles of Structure and Reactivity, Harper and Row Publishers, New York, NY, USA, 3rd edition, 1983.

[36] F. A. Cotton, G. Wilkinson, C. A. Murillo, and M. Bochmann, Advanced Inorganic Chemistry, John Wiley, New York, NY, USA, 6th edition, 1999. 

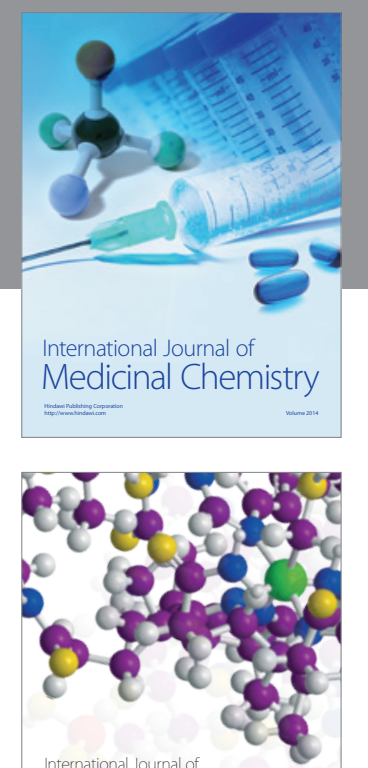

\section{Carbohydrate} Chemistry

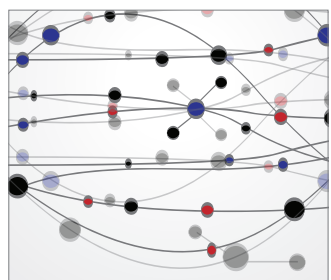

The Scientific World Journal
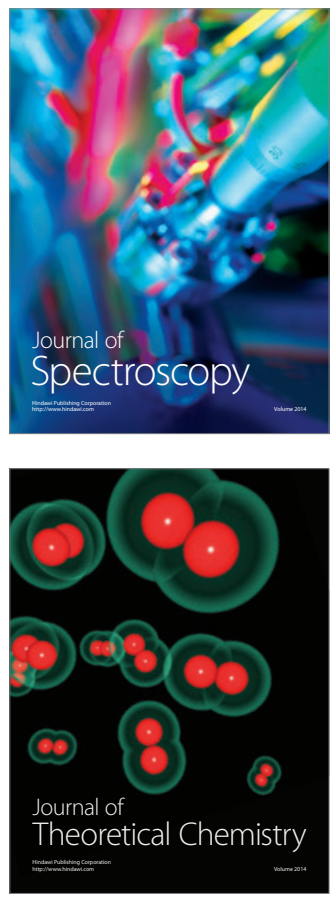
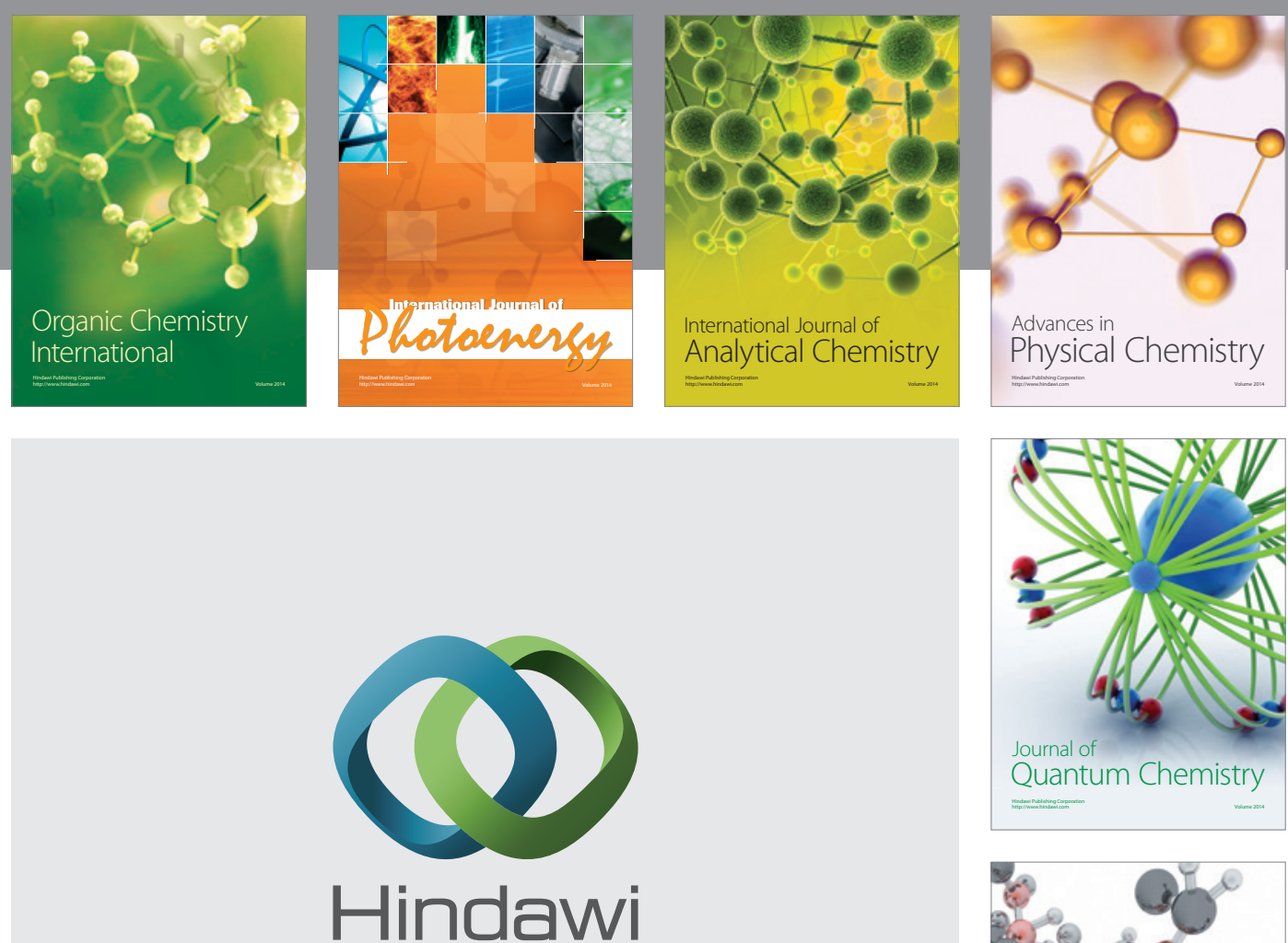

Submit your manuscripts at

http://www.hindawi.com

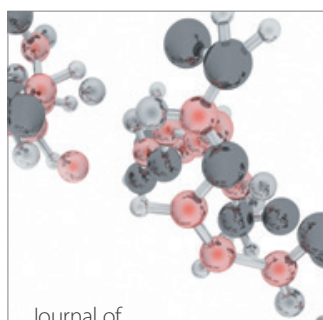

Analytical Methods

in Chemistry

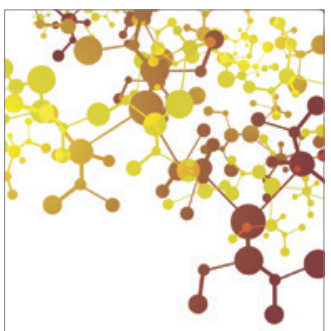

Journal of

Applied Chemistry

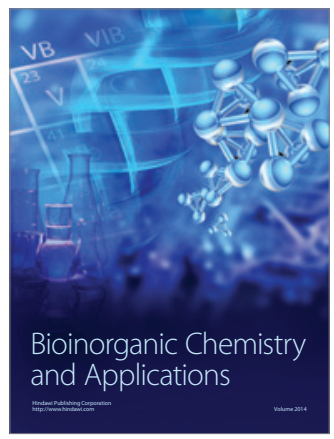

Inorganic Chemistry
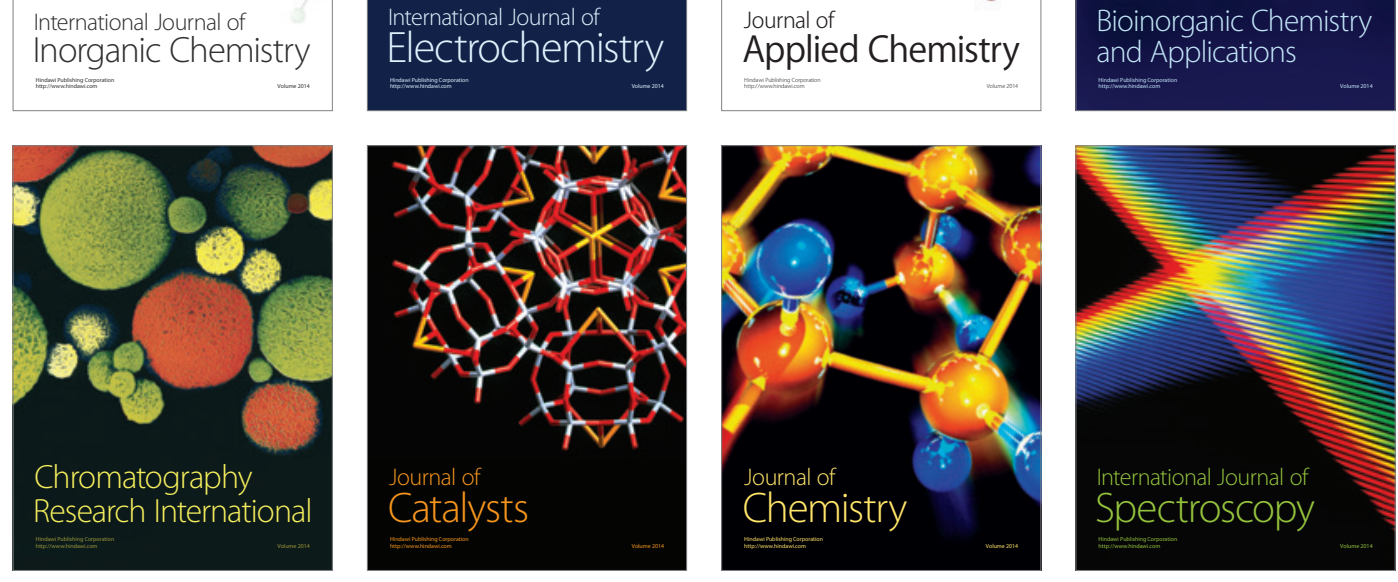